\title{
Photoinduced Intramolecular Substitution Reaction of Aryl Halide with Carbonyl Oxygen of Amide Group ${ }^{\dagger}$
}

\author{
Yong-Tae Park, Myong-Geun Song, Moon-Sub Kim, and Jeong-Hee Kwon \\ Department of Chemistry, Avmgpook Vational Linwersity. Daegu 702-701, Korea \\ Received February 15. 2002
}

\begin{abstract}
Photoreaction of $\mathrm{H}-(0$-hilopheny $)$ acetanide in basic acetonitrile produces an intramolecular substituted product. 2-methylbenzoxazole in addition to reduced product. acetanilide, whereas photoreaction of $\mathrm{A-}(0-$ halobenz: l)acetamide affords a reduced product. $N$-benzy lacetanide only: On the basis of preparative reaction. kinetics. and UV/ris absorption behavior, an electrophilic aromatic substitution of aryl halide with oxygen of its amide bond are proposed.
\end{abstract}

Key Words : $\mathrm{N}-((0-\mathrm{H}$ alophenyl)acetamide. $\mathrm{A}-(o-\mathrm{Haloben} / \mathrm{y})$ acelamide. Intramolecular pholosubstitution. Photoreduction. Methy lbenzoxazole

\section{Introduction}

We are interested in intramolecular photosubstitution of aryl halide with its amide and thioanide groups. There are a few reports for intramolecular photosubstitution of aryl halide with sulfur of its thioamide: intramolecular photosubstitution of halide ion of $o$-halothioacetanilide and $o$ halothiobenzanilide with sulfur of thioamide group produced 2-methy lbenzothiazole and 2-phenylbenzothiazole, respectively: $:^{i-3}$ intramolecular photosubstitution of halide ion of $N$-(2-chloro-3-pyridinyl)arylamide with sulfur of thioamide yielded 2-pheny lthiazolo $[5,+-b]$ pyridine. ${ }^{+}$These reactions are straightforward and valuable in synthesis of thiazole derivatives.

We have recently reported intramolecular photosubstitution of $N$-(2-halopheny l)arenecarboxamide and $N$-(2-halopheny l)cyclohexanecarboxamide with carbonyl oxygen of anide portion to yield 2-arylbenzoxazole and 2-cyclohexylbenzoxazole. respectively ${ }^{5-7}$ and mechanism of the reaction. ${ }^{5}$ The mechanism is that at charge-transfer state an electrophilic addition of oxygen of amide group to the halophenyl anion radical to give a cyclohexadienyl anion radical and eventually elimination of halide ion produce pyridiny lbenzoxazole. We hope to extend the reaction to $o$-haloacetanilide and clarify the mechanism for intramolecular photosubstitution of $\mathrm{N}$-(2-halophenyl)alkanecarboxamide.

\section{Results and Discussion}

Two $N$-(o-halophenyl)acetamide (1a, 1b) were synthesized by acetylation of 2-haloaniline with acetic andydride in weak acidic condition (Scheme 1). $\mathrm{N}$-(o-Halopheny l) $\mathrm{N}$ methylacetamide (2a. 2b) were prepared by methylation of 1a and 1b with methyl iodide in basic acetone. ${ }^{*} N$-(oHalobenzyl)acetanide (3a. 3b) were synthesized by acetylation of $o$-halobenzy lamine with acetic anlydride in weak

\footnotetext{
†This paper is dedicated to Sang-Chul Shim, exeeplional seientist, tematkable man.
}

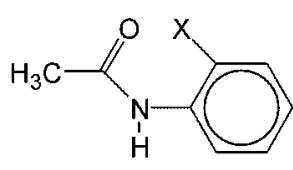

1a: $\mathrm{X}=\mathrm{Cl}$

$1 \mathrm{~b}: \mathrm{X}=\mathrm{Br}$

1c $: X=I$

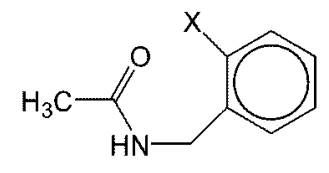

3a: $\mathrm{X}=\mathrm{Cl}$

3b $: \mathrm{X}=\mathrm{Br}$

\section{Scheme 1}

acidic condition. The haloarylacetanides 1.2 and $o$-halobenzylanides 3 have been identified by the spectral properties ('H NMR. UV. IR, mass spectra) and elemental analy ses.

When an acetonitrile solution of $\mathrm{N}$-(o-bromophenyl)acetamide (1b) containing aqueous $\mathrm{NaOH}$ was irradiated by a $\mathrm{Hg}$ lamp under nitrogen. intramolecular substituted product. 2-methy lbenzoxazole (4) and reduced product, acetanilide (5) were obtained in 27 and $13 \%$ vields. respectively (Scheme 2). 2-Methylbenzoxazole could be easily identified by the ${ }^{\prime} \mathrm{H}$ NMR spectra. Four aronatic protons appear at a range of $\delta 7.20-7.60$. whereas methyl protons occur at $\delta 2.55$ as a singlet (Figure 1): two aronlatic protons near oxygen

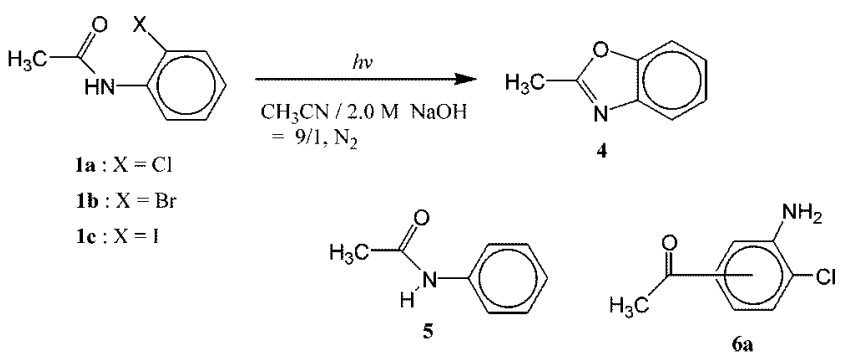

Scheme 2 


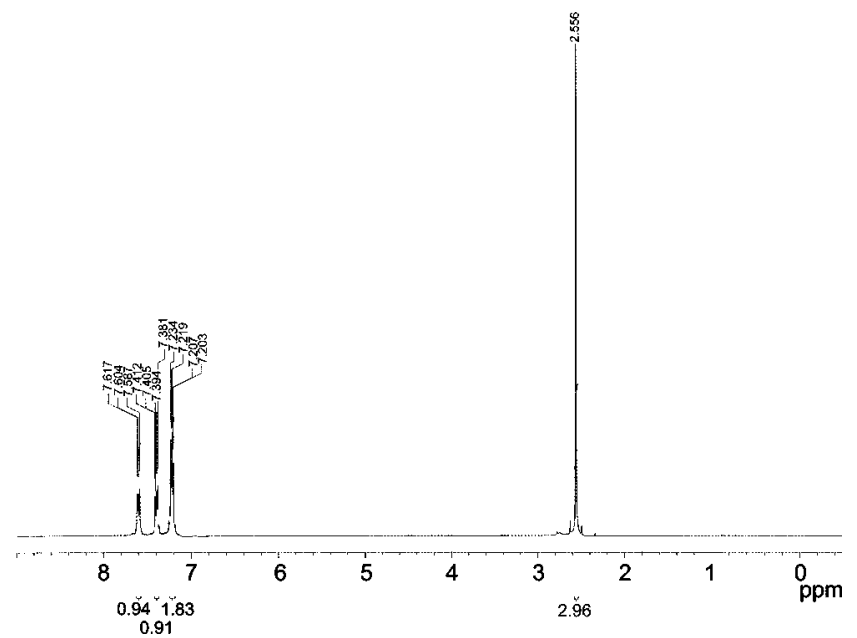

Figure 1. 'II NMR spectra of 2-1nethỵ.lbenzoxazole in $\mathrm{Cl})\left.\mathrm{C}\right|_{3}$.

Table 1. Product Yidds in the Photoreations of $X^{\prime}$-(o-halopheny $)$ acetamide (1) and $x^{\prime}$-(o-halobenz:l)acetamide (3)

\begin{tabular}{|c|c|c|c|c|c|c|c|}
\hline \multirow{2}{*}{$\begin{array}{l}\text { Slarting } \\
\text { compd }\end{array}$} & \multirow{2}{*}{$\begin{array}{l}\text { Solvent } \\
\text { condition }\end{array}$} & \multirow{2}{*}{$\begin{array}{l}\text { Reation } \\
\text { timne (min) }\end{array}$} & \multicolumn{4}{|c|}{ Product yicld $(\%)$} & \multirow{2}{*}{$\begin{array}{c}\text { Recovered } \\
(\%)\end{array}$} \\
\hline & & & 4 & 5 & $6 \mathrm{a}$ & 8 & \\
\hline $1 \mathbf{a}$ & $\begin{array}{l}\mathrm{C} \cdot \mathrm{H}_{3} \mathrm{C} \mathrm{N} / 2 \mathrm{M} \\
\mathrm{Na}(\mathrm{ll}=9 / 1\end{array}$ & 40) & 10 & & $5^{a}$ & & 3 \\
\hline $1 b$ & $\begin{array}{l}\mathrm{Cl}_{3} \mathrm{CN} / 2 \mathrm{M} \\
\mathrm{NaOl}=9 / 1\end{array}$ & 30 & 27 & 13 & & & 6 \\
\hline $1 \mathrm{c}$ & $\begin{array}{l}\mathrm{Cl}_{3} \mathrm{CN} / 2 \mathrm{M} \\
\mathrm{NaOll}=9 / 1\end{array}$ & 20) & 4 & 33 & & & 3 \\
\hline $3 \mathbf{a}$ & $\begin{array}{l}\mathrm{CH} \mathrm{C}_{2} \mathrm{~N} / 2 \mathrm{M} \\
\mathrm{Na}(\mathrm{ll}=9 / 1\end{array}$ & 45 & & & & 27 & 3 \\
\hline $3 b$ & $\begin{array}{l}\mathrm{CH}_{2} \mathrm{CN} / 2 \mathrm{M} \\
\mathrm{NaOll}=9 / 1\end{array}$ & 25 & & & & 33 & 8 \\
\hline
\end{tabular}

"identified by GC MS only:

and nitrogen of oxazole ring appear at rather low ficlds ( $\delta$ 7.60 and 7.40, respectively) and two aromatic protons farther oxygen and nitrogen occur at a little higher field $(\delta 7.20)$. Acetanilide was identified by comparing its ${ }^{1} \mathrm{H}$ NMR spectra with that of authentic sample.

The pertinent results of synthetic photoreactions of $\mathbf{1 .} 2$. and 3 are shown in Table 1 and Scheme 2. Chloro analog 1a produced substituted product $4(10 \%)$ and Fries type product $6(5 \%) .{ }^{\circ}$ Iodo analog $1 \mathrm{c}$ also produced 2-methy lbenzoxazole $(4 \%)$ and acetanilide $(33 \%)$.

Intramolecular substitution reactions occur in the photoreactions of all halophenyl acetamides 1a. 1b. and 1c. photoFries type reaction from only 1a. and photoreduction reaction from $1 \mathrm{c}$ and $\mathbf{1 b}$. This results can be explained by the strength of $\mathrm{C}-\mathrm{X}$ bond: weak $\mathrm{C}-\mathrm{I}$ bond of $1 \mathrm{c}$ is readily cleaved by excitation to give phenyl and iodine radicals. eventually producing mainly reduced product 5 ; strong $\mathrm{C}-\mathrm{Cl}$ bond of 1 a is inert to the excitation. inducing two alternative reactions. intramolecular substitution leading to benzoxazole 4 and Fries type reactions to $6 \mathrm{a}$ : and medium $\mathrm{C}-\mathrm{Br}$ bond of $1 \mathrm{~b}$ is not only cleaved but also substituted by excitation. eventually producing 4 and 5 .

$N$-(o-Clloropheny l) $-N$-methylacetamide (2a) or $N$-(o-

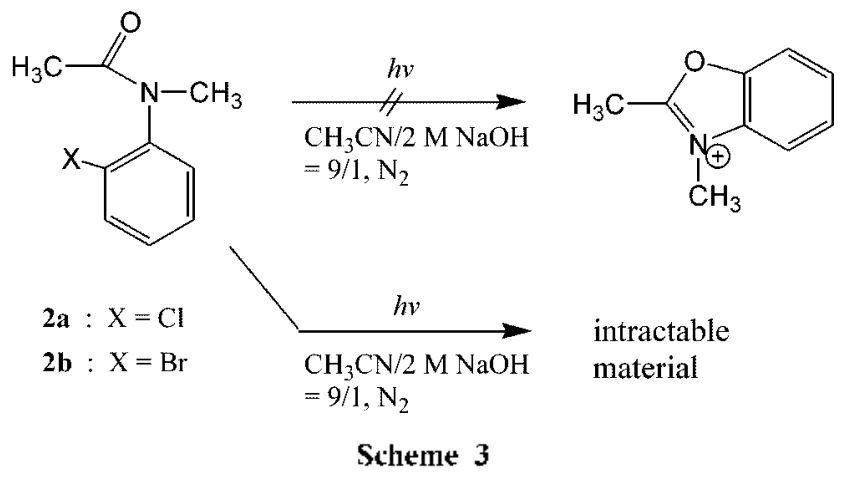

bromopheny l)- $N$-methy lacetanide (2b), which can not exist as imidol form in contrast to 1 a-c. did not produce intramolccular substitution product but intractable matcrials in the above condition (Scheme 3). This results imply that an imidol form is possibly involved in the intramolecular substitution of 1 as observed in the case of $N$-(o-halopheny)py ridinccarboxamide. ${ }^{5}$

$N$-(o-Chlorobensyl)acetamide (3a) and $N$-(o-bromobenzal)acctamide (3b) did not produce intramolccular substituted product 7. but reduced product 8 in the condition (Scheme 4). These substrates can not procecd to a charge-transfer species by excitation because of nonconjugation between the amide group and 2-halophenyl group and thus. reduction reaction occurs cxclusively. This results support that conjugated imidolate in a charge transfer state is imolved in the intramolccular photosubstitution of 1.

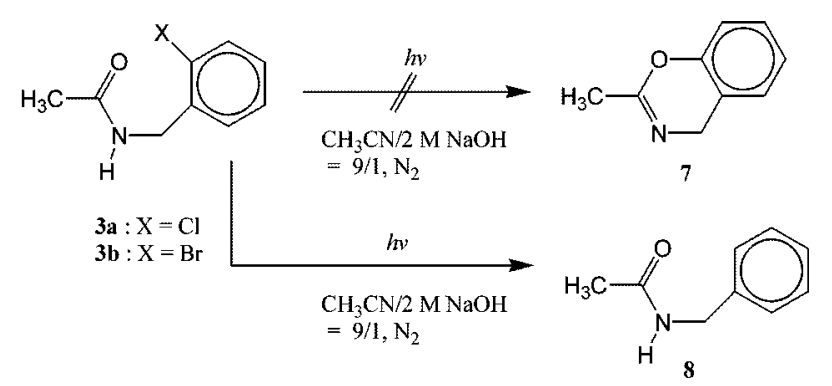

Scheme 4

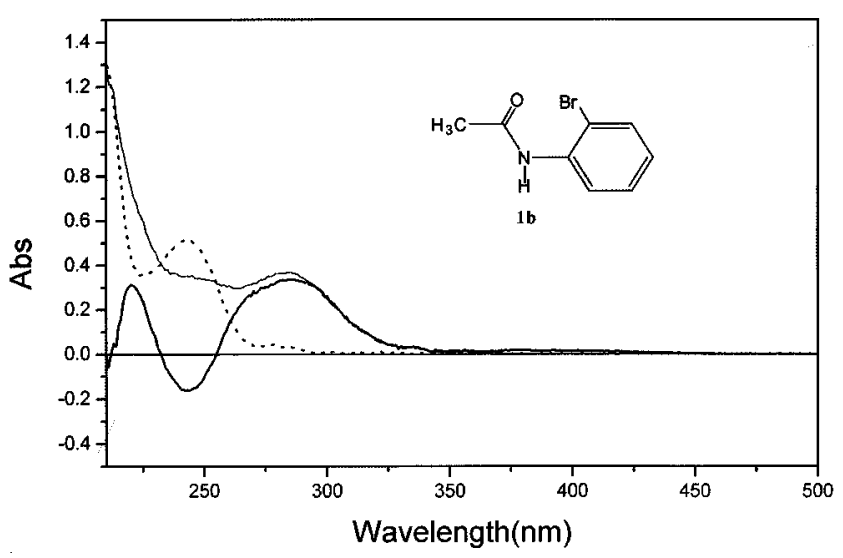

Figure 2. UV/vis absorption change of $1 \mathbf{b}$ :---, UV/vis absorption spectra of $1 \mathbf{b}$ in acetonitrile: - that of $1 \mathbf{b}$ in acetonitrile containing $\mathrm{NaOH}$ - - this spectra was obtained by subtraction of dotted line from the thin line. 
Table 2. Relative Rate of the lionation ol Products in the Photoreaction of $\mathrm{V}$-(2-bromophenyl)acetamide (1b) with a monochromatic Light $(200 \pm 10 \mathrm{~nm})$

\begin{tabular}{|c|c|c|c|c|}
\hline \multirow{2}{*}{ Fintry } & \multirow{2}{*}{ Medium } & \multirow{2}{*}{$\Lambda \mathrm{tm}$} & \multicolumn{2}{|c|}{ Rell. rata } \\
\hline & & & 4 & 5 \\
\hline I & $\mathrm{CH}_{3} \mathrm{CNN}$ & $\mathrm{N}_{2}$ & 1.8 & 0.1 \\
\hline 2 & $\mathrm{CH}_{3} \mathrm{CN} / \mathrm{NaOH}^{\mathrm{t}}$ & $\mathrm{N}_{2}$ & 2.7 & 0.2 \\
\hline 3 & $\mathrm{CH}_{3} \mathrm{CN}$ & $\mathrm{O}_{2}$ & 1.8 & $\mathrm{nd}^{*}$ \\
\hline 4 & $\mathrm{CH}_{3} \mathrm{CN} / \mathrm{NaOH} \mathrm{H}^{\mathrm{t}}$ & $\mathrm{O}_{2}$ & 2.7 & $n d^{*}$ \\
\hline 5 & Benzene & $\mathrm{N}_{2}$ & 1.0 & 0.1 \\
\hline 6 & $\mathrm{C}_{3} \mathrm{OH}$ & $\mathrm{N}_{2}$ & 0.8 & 1.9 \\
\hline 7 & $\mathrm{C}_{3} \mathrm{CN} / \mathrm{F} \cdot \mathrm{t}_{3} \mathrm{~N}(2.1 \mathrm{mM})$ & $\mathrm{N}_{2}$ & 2.4 & 0.5 \\
\hline 8 & $\left.\mathrm{CH}_{3} \mathrm{CN} / \mathrm{MM} \wedge^{b} 5.6 \mathrm{mM}\right)$ & $\mathrm{N}_{2}$ & 2.7 & 1.2 \\
\hline 9 & $\begin{array}{c}\mathrm{CH}_{3} \mathrm{CN} / 2 \mathrm{M} \mathrm{NaOH} \\
\text { Isoprene }(0.5 \mathrm{mM})\end{array}$ & $\mathrm{N}_{2}$ & 2.1 & 0.4 \\
\hline
\end{tabular}

"lhe concentration of $1 \mathbf{b}$ is $4 \times 10^{3} \mathrm{M}$. "methyl methacrylate. " $\mathrm{CH}_{3} \mathrm{CN}$ $2 \mathrm{M} \mathrm{NaOIJ}-132$. "not detected in $G \mathrm{C}$ used

Blanks reactions were performed. The thermal reaction of $1 \mathbf{a}$ and $\mathbf{1 b}$ under the above conditions for 2 days did not produce a substituled or reduced product. Thus. the reaction that produced 2-methylben\%oxarole and acclanilide are not thermal reactions but photoinduced substitution and reduction reactions.

In order to study the mechanism of the reaction of 1 . the $U \mathrm{~V} / \mathrm{is}$ absorption behavior and relative rates of $\mathbf{1 b}$ were mcasured under scyeral conditions (Figure 2 and Table 2). A typical absorption of $\mathbf{1 b}$ in acctonitrilc changed to a shapeless spectra in the presence of bases such as $\mathrm{NaOH}$ (Figure 2) or $\mathrm{KOH}$ (not shown). If subtraction of the typical spectra of $1 \mathrm{~b}$ from the shapeless spectra. an absorption peak at about $290 \mathrm{~nm}$ appeared. It is belicicd that the new absorption is duc to its charge-transferred singlet state and the state is related to the intramolccular photosubstitution as in the case of $N$-(o-halopheny])py ridinccarboxamide. The conchusion is supported by the following observation that the charge-transferred species could not observed for substrate $\mathbf{2}$ and 3 . in which charge-transferred excited states are not possible stnicturally:

In the presence of base. substitution and reduction rates in the photoreaction of $1 \mathrm{~b}$ with monochromatic light increased (entries 1. 2). The presence of oxygen did not affect the substitution but reduction (entries 3.4). This result indicates that singlet states are inrolved in the substitution and triplet states involved in the reduction. The substitution rate decreased in benzene whereas in methanol, substitution rate decreased and reduction rate increased somewhat. The presence of trietlylamine increased both substitution and reduction rate in a small extent. Methyl methacrylate (MMA) or isoprene. radical scavengers did not give an effect on substitution but increased reduction somewhat. Increase of reduction rate in the presence of methanol. MMA and isoprene can be explained in term of ease asailability of hydrogen atom from these substances. No effect of radical scasenger on the substitution implies that the substitution reaction is not a radical-mediated reaction.

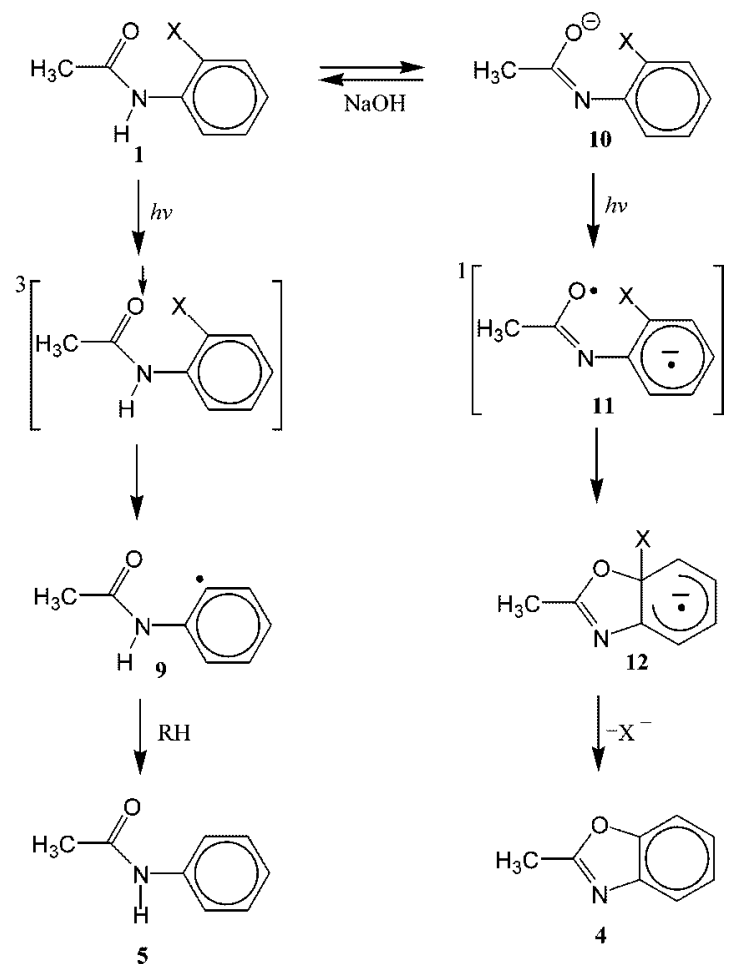

Scheme 5

Elcctrophilic addition and climination mechanism for the substitution reaction and radical mechanism for reduction reaction are proposed (Scheme 5). The triplet state through intersystem crossing of singlet state of 1 provides energy to cleave $\mathrm{C}-\mathrm{X}$ bond of 1 homolytically. produce pheny 19 and halogen radicals. and crentually give reduced product 5 . In base such as $\mathrm{NaOH}$. imidolate anion form 10 is cquilibrated in a moderate amount with the keto form. Excitation of the imidolate anions 10 generates singlet charge-transferred spccics 11. Elcctrophilic addition of imidolatc radical 11 to 2-halophenyl anion radical to form cyclohexadienyl anion radical 12 and then elimination of halide ion gives substitution product 4.

\section{Experimental Section}

General procedure for the preparation of $N$-(o-halophenyl)acetamide (1). In a $20 \mathrm{~mL}$. three-necked, roundbottomed flask with a dropping fummel, thermoneter. and condenser is placed $3.4 \mathrm{~mL}$ of 2-chloroaniline $(0.03 \mathrm{~mole})$. To the stirred solution are added $3.6 \mathrm{mIL}$ of acetic anlydride (0.03 mole) slowly within $70^{\circ} \mathrm{C}$ and $7 \mathrm{~mL}$ of dilute chloric acid $(0.1 \mathrm{M})$. The mixture is stirred at $80^{\circ} \mathrm{C}$ for $2 \mathrm{~h}$. The flask is kept at room temperature for 20 min and product isolated by suction filteration. The crystals is washed with water triply. The recrystallization fron $n$-hexane gives $4.8 \mathrm{~g}$ of $N$ - $(o$-chlorophenyl)acetanide.

$N$-(o-Chlorophenyl)acetamide (1a): yield $4.8 \mathrm{~g}(88 \%)$ : mp 87-88 ${ }^{\circ} \mathrm{C}: \mathrm{UV}\left(\lambda_{\text {tnax }}\right.$ in $\left.\mathrm{CH}_{3} \mathrm{CN}\right) 239 \mathrm{~nm}\left(\varepsilon=1.1 \times 10^{4} \mathrm{~L} /\right.$ mole-cm): IR ( $\left.\mathrm{CHCl}_{3}\right) 3242.3044,1663 \mathrm{~cm}^{-1}:{ }^{1} \mathrm{H}-\mathrm{NMR}$ (300 MHz. $\left.\mathrm{CDCl}_{3}\right) \delta 8.38($ d. $J=7.8 \mathrm{~Hz} . \mathrm{lH}: \mathrm{C} 3-\mathrm{H}$ of $\mathrm{Pl}$ ). 
7.64 (br. s. $1 \mathrm{H} . \mathrm{NH}) .7 .38(\mathrm{~d} . J=7.8 \mathrm{H} z, \mathrm{lH} . \mathrm{C}(\mathrm{-H}$ of $\mathrm{Ph})$. $7.28\left(1 . J=7.8 \mathrm{H} z_{0}\right.$ l $\mathrm{H}_{.} \mathrm{C}_{4}-\mathrm{H}$ of Ph). $7.04(\mathrm{t} . J=7.8 \mathrm{H} z . . \mathrm{lH}$. $\mathrm{C}_{5}-\mathrm{H}$ of $\mathrm{Ph}$ ). 2.25 (s. $3 \mathrm{H} . \mathrm{CH}_{3}$ ): MS (El) $\mathrm{m} / /$ (rel intensity) 171 (7. $\left.\mathrm{M}^{\prime}+2\right), 169\left(20, \mathrm{M}^{\prime}\right), 134\left(48, \mathrm{M}^{\prime}-\mathrm{Cl}\right), 127(100)$.

Anal. Calcd for $\mathrm{C}_{\S} \mathrm{H}_{\S} \mathrm{ONCl}: \mathrm{C} .56 .65: \mathrm{H}, 4.75 ; \mathrm{N}, 8.26$. Found: C. 57.68: H. 4.93: N. 8.11.

$N$-(o-Bromophenyl)acetamide (1b): vield $5.5 \mathrm{~g}(80 \%)$ : mp 92-93 ${ }^{\circ} \mathrm{C}$ : UV $\left(\dot{\lambda}_{\max }\right.$ in $\left.\mathrm{CH}_{3} \mathrm{CN}\right) 242 \mathrm{~nm}\left(\varepsilon=8.1 \times 10^{3} \mathrm{~L} /\right.$ molc-cm): IR $\left(\mathrm{CHCl}_{5}\right) 327 \% .3032,1660 \mathrm{~cm}^{-1}:{ }^{1} \mathrm{H}-\mathrm{NMR}$ (300 $\left.\mathrm{MH} / . \mathrm{CDCl}_{3}\right) \delta 8.35\left(\mathrm{~d} . J=7.8 \mathrm{H} \% . \mathrm{lH} . \mathrm{C}_{3}-\mathrm{H}\right.$ of $\left.\mathrm{Ph}\right)$. 7.62 (br. s. lH. NH). 7.55 (d. $J=7.8 \mathrm{~Hz} ., \mathrm{lH} . \mathrm{C}_{6}-\mathrm{H}$ of $\mathrm{Pl}$ ). $7.34\left(1 . J=7.5 \mathrm{H} z .1 \mathrm{H} . \mathrm{C}_{4}-\mathrm{H}\right.$ of $\left.\mathrm{Ph}\right) .6 .98(\mathrm{l} . J=7.5 \mathrm{H} / .1 \mathrm{H}$. $\mathrm{C}_{5}-\mathrm{H}$ of $\mathrm{Ph}$ ). 2.17 (s. $3 \mathrm{H} . \mathrm{CH}_{3}$ ): MS (EI) $\mathrm{m} / \%$ (rel intensity) $215\left(2 . \mathrm{M}^{\prime}+2\right) .213(2 . \mathrm{M}) .170(100)$.

Anal. Calcd for $\mathrm{C}_{8} \mathrm{H}_{8} \mathrm{ONBr}$ : C. 44.89: H. 3.77: N. 6.54. Found: C. 45.02: H. 3.75: N.6.25.

$N$-(o-lodophenyl)acetamide (1c): yicld $5.9 \mathrm{~g}(71 \%): \mathrm{mp}$ 104-105 ${ }^{\circ} \mathrm{C}$ : UV $\left(\lambda_{\text {max }}\right.$ in $\left.\mathrm{CH}_{3} \mathrm{CN}\right) 236 \mathrm{~nm}\left(\varepsilon=1.2 \times 10^{3} \mathrm{~L} /\right.$ molc-cm): IR $\left(\mathrm{CHCl}_{3}\right) 3272.3028 .1660 \mathrm{~cm}^{-1}:{ }^{1} \mathrm{H}-\mathrm{NMR}$ (400 MH $\left.\% \mathrm{CDCl}_{3}\right) \delta 8.20\left(\mathrm{~d} . J=7.9 \mathrm{H} \% . \mathrm{lH} . \mathrm{C}_{3}-\mathrm{H}\right.$ of $\left.\mathrm{Ph}\right)$. $7.79\left(\mathrm{~d} . J=7.9 \mathrm{H} \% \mathrm{lH} . \mathrm{C}_{6}-\mathrm{H}\right.$ of $\left.\mathrm{Ph}\right) .7 .36$ (br. s. $\left.\mathrm{lH} . \mathrm{NH}\right)$. $7.34\left(1 . J=7.9 \mathrm{H} / . \mathrm{lH} . \mathrm{C}_{4}-\mathrm{H}\right.$ of $\left.\mathrm{Ph}\right) .6 .85(\mathrm{t} . J=7.9 \mathrm{H} \% \mathrm{lH}$. $\mathrm{C}_{5}-\mathrm{H}$ of $\mathrm{Ph}$ ). 2.25 (s. $\left.3 \mathrm{H}, \mathrm{CH}_{3}\right)$ : MS (EI) $\mathrm{m} / \%$ (rel intensity) $260\left(13, M^{\prime}\right) .134\left(100 . M^{\prime}-1\right)$.

Anal. Calcd for $\mathrm{C}_{8} \mathrm{H}_{8} \mathrm{ONI}$ : C. 36.81: H. 3.09: N. 5.37. Found: C. 37. 12: H. 2.70: N. 5.03.

Preparation of $N$-(0-halophenyl)- $N$-methylacetamide (2). $N$-Methy lation of $N$-(o-halopheny l)acetamide (2a. 2b) was performed by using Jolunstone method

$\mathrm{N}$-(o-Chlorophenyl)- $\mathrm{N}$-methylacetamide (2a): vicld 0.74 g $(81 \%)$ : UV ( $\lambda_{\text {max }}$ in $\left.\mathrm{CH}_{3} \mathrm{CN}\right) 272 \mathrm{~nm}\left(\varepsilon=2.1 \times 10^{3} \mathrm{~L} /\right.$ molc-cm): [R $\left(\mathrm{CHCl}_{3}\right) 3062.2934 .1668 \mathrm{~cm}^{-1}$ : ${ }^{1} \mathrm{H}-\mathrm{NMR}$ (400) $\left.\mathrm{MH} \%, \mathrm{CDCl}_{3}\right) \delta 7.53(\mathrm{dt} . J=9.4 \mathrm{H} \% . \mathrm{lH}$. of $\mathrm{Ph}) .7 .36$ (dd. $J=6.1 \mathrm{H} \% 2 \mathrm{H}$. of Ph). $7.30(\mathrm{dt} . J=9.4 \mathrm{H} \% \mathrm{lH}$. ol $\mathrm{Ph}$ ). 3.20 (s. $3 \mathrm{H} . \mathrm{N}-\mathrm{CH}_{3}$ ). 1.81 (s. $3 \mathrm{H}, \mathrm{CH}_{3}$ ): $\mathrm{MS}(\mathrm{El}) \mathrm{m} / \%(\mathrm{rcl}$ intensity) $186(16 . \mathrm{M}+3), 184(50, \mathrm{M}+1) .148(100)$.

Anal. Calcd for $\mathrm{C}_{0} \mathrm{H}_{10} \mathrm{ONCl}$ : C. 58.87; H. 5.49; N.7.63. Found: C. $58.70 ;$ H. 5.41: N. 7.43 .

$N$-(o-Bromophenyl)- $N$-methylacetamide (2b): Yield 0.97 g $(86 \%): \mathrm{UV}\left(\lambda_{\text {max }}\right.$ in $\left.\mathrm{CH}_{3} \mathrm{CN}\right) 270 \mathrm{~mm}\left(\varepsilon=3.2 \times 10^{3} \mathrm{~L} /\right.$ mole-cm): IR $\left(\mathrm{CHCl}_{3}\right) 3059.2932 .1668 \mathrm{~cm}^{-1}$ : ${ }^{1} \mathrm{H}-\mathrm{NMR}$ $\left(400 \mathrm{MHz}, \mathrm{CDCl}_{3}\right) \delta 7.75(\mathrm{~d}, J=8.1 \mathrm{~Hz} .1 \mathrm{H} . \mathrm{C} . \mathrm{H}$ of $\mathrm{Ph})$. 7.37 (t. $J=8.1 \mathrm{~Hz} .1 \mathrm{H} . \mathrm{C}_{4}-\mathrm{H}$ of $\mathrm{Ph}$ ). 7.30 (m. $2 \mathrm{H}$ ). 3.19 (s. $3 \mathrm{H} .-\mathrm{NCH}_{3}$ ). 1.81 (s. $\left.3 \mathrm{H} . \mathrm{CH}_{3}\right) ; \mathrm{MS}(\mathrm{EI}) \mathrm{m} / \mathrm{z}$ (rel intensity) $229\left(4 . \mathrm{M}^{+}+2\right) .227\left(4 . \mathrm{M}^{-}\right), 148\left(100 . \mathrm{M}^{-}-\mathrm{Br}\right)$.

Anal. Calcd for $\mathrm{CoH}_{10} \mathrm{ONBr}: \mathrm{C}, 47.39 ; \mathrm{H} .4 .42 ; \mathrm{N}, 6.14$. Found: C. 47.43; H, 4.25; N. 6.03 .

General procedure for the preparation of $N$-(o-halobenzyl)acetamide (3). In a $20 \mathrm{~mL}$. three-necked, round-bottomed flask with a dropping fumel. thermometer. and condenser is placed $0.6 \mathrm{~mL}$ of 2 -chlorobenzy lamine ( $5 \mathrm{mmole}$ ). To the stirred solution are added $1 \mathrm{~mL}$ of acetic anlydride $(10$ mumole) solution within $70^{\circ} \mathrm{C}$ and $10 \mathrm{~mL}$ of chloric acid $(0.1$ $\mathrm{M})$. The mixture is stirred at $80{ }^{\circ} \mathrm{C}$ for $2 \mathrm{~h}$. The flask is kept at room temperature for $20 \mathrm{~min}$ and the product isolated by suction filteration. The crystals are washed with water. The recrytallization from n-hexane gives $0.85 \mathrm{~g}$ of $\mathrm{N}$-(o- chloroben $x$ l)acetamide ( $3 \mathbf{a})$

$N$-(o-Chlorobenzyl)acetamide (3a): yicld $0.85 \mathrm{~g}(75 \%)$ : mp 60-61 ${ }^{\circ} \mathrm{C}$ : UV $\left(\lambda_{\max }\right.$ in $\left.\mathrm{CH}_{3} \mathrm{CN}\right) 26+\mathrm{nm}\left(\varepsilon=2.2 \times 10^{+} \mathrm{L} /\right.$ mole-cm): IR $\left(\mathrm{CHCl}_{3}\right) 3264,3085,1642 \mathrm{~cm}^{-1}$. 'H-NMR $\left(400 \mathrm{MH} / . \mathrm{CDCl}_{3}\right) \delta 7.40(\mathrm{~m} .2 \mathrm{H}) .7 .24(\mathrm{~m} .3 \mathrm{H}) .5 .89$ (br. s. lH. NH), $4.05\left(\mathrm{~d} . J=6,0 \mathrm{H} / 2 \mathrm{H} . \mathrm{CH}_{2}\right) .2 .20$ (s. $\left.3 \mathrm{H} . \mathrm{CH}_{3}\right)$ : MS (El) $\mathrm{m} / \mathrm{k}$ (rel intensity) $185\left(2, \mathrm{M}^{\prime}+2\right) .183\left(7 . \mathrm{M}^{\prime}\right) .148$ (loo).

Anal. Caled for $\mathrm{C}_{3} \mathrm{H}_{40} \mathrm{ONCl}: \mathrm{C} .58 .87: \mathrm{H}, 5.49: \mathrm{N}, 7.63$. Found: C. 59.32: H, 5.65: N. 7.32 .

$N$-(o-Bromobenzyl)acetamide (3b): Yicld $0.82 \mathrm{~g}(80 \%)$ :

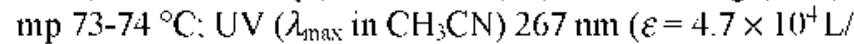
molc-cm): IR $\left(\mathrm{CHCl}_{3}\right): 3298,3084,16+2 \mathrm{~cm}^{-1}:{ }^{1} \mathrm{H}-\mathrm{NMR}$ $\left(400 \mathrm{MH} \approx \mathrm{CDCl}_{3}\right) \delta 7.57(\mathrm{~d} . J=8.1 \mathrm{H} \% \mathrm{lH}) .7 .30(\mathrm{~m} .3 \mathrm{H})$. 5.92 (br. s. IH. NH). 4.53 (d. $J=6,0 \mathrm{H} \% 2 \mathrm{H} . \mathrm{CH}_{2}$ ). 2.03 (s. $\left.3 \mathrm{H}, \mathrm{CH}_{3}\right)$ : MS (El) $\mathrm{m} / \%$ (rel intensity) $230\left(1, \mathrm{M}^{\prime}+2\right) .228(\mathrm{l}$. M). $148(100)$.

Anal. Caled for $\mathrm{C}_{0} \mathrm{H}_{10} \mathrm{ONBr}: \mathrm{C}, 47.39: \mathrm{H}, 4.42: \mathrm{N}, 6.14$. Found: C. 47,28: H, 4.34: N, 6,02.

\section{Preparative Photoreaction.}

Photoreaction of $N$-(o-Bromophenyy)acetamide (1 b)General procedure: To a large $(500 \mathrm{~mL}$ ) quart immersion wcll photolysis unit with provision for circulation of nitrogen were added $450 \mathrm{~mL}$ of acctonitrilc. $N$-(obromophenyl)acctamide ( $96 \mathrm{mg} .0 .45 \mathrm{mmolc})$. and $50 \mathrm{~mL}$ of $2 \mathrm{M}$ aqueous $\mathrm{NaOH}$. With nitrogen circulation. the mixture was irradiated with a $450 \mathrm{~W}$ mercury lamp (medium pressurc) for $30 \mathrm{~min}$. The resulting two-phase mixtures were scparated and water layer was extracted with ethyl acctatc. The acconitrile and ethyl acctate portions were together craporated and analyzed by TLC. The TLC with eluent nHexanc/EA $=5 / \mathrm{l}$ gave two spot: $R_{f} 0.48$ and $R_{f} 0.2 \mathrm{l}$. The substance of $\mathrm{R}_{\mathrm{f}} 0.48$ is identificd as 2-melhylbenroxazolc: yicld $16 \mathrm{mg}$ (27\%): IR $\left(\mathrm{CHCl}_{3}\right) 3050.1620 \mathrm{~cm}^{-1}$ : ${ }^{~} \mathrm{H}-\mathrm{NMR}$ (300 $\left.\left.\mathrm{MH} \% \mathrm{CDCl}_{3}\right): \delta 7.60\right)\left(\mathrm{m} . \mathrm{lH} . \mathrm{C}_{8}-\mathrm{H}\right) .7 .40\left(\mathrm{~m} . \mathrm{lH} . \mathrm{C}_{5-}\right.$ H). $7.20\left(\mathrm{~m} .2 \mathrm{H} . \mathrm{C}_{67}-\mathrm{H}\right) .2 .55$ (s. $\left.3 \mathrm{H} . \mathrm{CH}_{3}\right)$ : MS (EI) m/x (rel intensity) $133(100 . \mathrm{M}) .104(19)$.

Anal. Calcd for $\mathrm{C}_{8} \mathrm{H}_{7} \mathrm{ON}$ : C. 72.16: H. 5.30: N. 10.52 . Found: C. 71.93 ; H. 5.48: N. 10.87.

The substance of the $\mathrm{R}_{\mathrm{f}} 0.21$ is identified as $N$-phenyacetamide: yield $8 \mathrm{mg}(13 \%)$ : 'H-NMR $\left(300 \mathrm{MHz}, \mathrm{CDCl}_{3}\right)$ $\delta 7.64$ (br. s. 1 H. NH). 7.50 (d. $J=6.0 \mathrm{~Hz} .1 \mathrm{H} . \mathrm{C}_{4}-\mathrm{H}$ of ph). 7.34 (t. $J=6.0 \mathrm{~Hz} .2 \mathrm{H} . \mathrm{C}_{3.5}-\mathrm{H}$ of ph). $7.13(\mathrm{t} . J=6.0 \mathrm{~Hz} .2 \mathrm{H}$. $\mathrm{C}_{2.6} \mathrm{H}$ of ph). 2.20 (s. $3 \mathrm{H} . \mathrm{CH}_{3}$ ).

Photoreaction of $\mathrm{N}$-2-(Chlomphenyl)acetamide (1a) and $\mathrm{N}$-2-(Iodophenyl)acetamide (1c): The photoreactions of $1 \mathrm{a}$ and $1 \mathrm{c}$ were carried out for $40 \mathrm{~min}$ and 20 , respectively as in the case of $1 \mathbf{b}$. In case of 1a. photo-Fries type product 6 a $(5 \%)$ was separated in addition to 2 -metlyy benzoxazole $(10 \%)$ and identified by GC/niass only. The products from $1 \mathbf{c}$ were the same as products from $\mathbf{1 b}$.

Photoreaction of $N$-(o-halophenyl)- $N$-methylacetamide, 2: The photoreaction of $\mathbf{2 a}$ and $\mathbf{2 b}$ were carried out as in the case of 1a. An intractable material was formed from both $\mathbf{2 a}$ and $2 \mathrm{~b}$.

Photoreaction of $N-(o$-halohenzyl)acetamide (3): The photoreaction of 3 was carried out as in the case of 1a. The 
TLC of the reaction product give a reduced product. Nben slacetamide: y ield $22 \mathrm{mg}$ (33\%): $\mathrm{mp} 46-47^{\circ} \mathrm{C}$ : UV ( $\lambda_{\max }$ in $\mathrm{CH}_{3} \mathrm{CN}$ ) nm: ${ }^{1} \mathrm{H}-\mathrm{NMR}\left(400 \mathrm{MH} / . \mathrm{CDCl}_{3}\right) \delta 7.35(\mathrm{~d}$. $J=6.0 \mathrm{H} z .1 \mathrm{H}, \mathrm{C}_{4}-\mathrm{H}$ of ph). $7.34\left(1 . J=8.5 \mathrm{H} z 2 \mathrm{H}, \mathrm{C}_{3.5}-\mathrm{H}\right.$ of ph). $7.28\left(1 . J=3.0 \mathrm{H} / 2 \mathrm{H} . \mathrm{C}_{2.6}-\mathrm{H}\right.$ of ph). $4.44(\mathrm{~d} . J=5.5$ $\left.\mathrm{H} / 2 \mathrm{H}_{2} \mathrm{CH}_{2}\right) .2 .03\left(\mathrm{~s} .3 \mathrm{H} . \mathrm{CH}_{3}\right): \mathrm{MS}(\mathrm{El}) \mathrm{m} / \mathrm{z}$ (rel intensity) $148\left(100, M^{\prime}\right) .139(16)$.

Relative Rate- General Procedure. $N$-(o-Bromophenyl)acclamide (1b. $8.5 \mathrm{mg}$ ) was dissolved in $10 \mathrm{~mL}$ of a solvent such as accionitrile/2 $\mathrm{M} \mathrm{NaOH}\left(4 \times 10^{-3} \mathrm{M}\right)$. The stock solution $(2.5 \mathrm{~mL})$ was placed in a UV cuvette and deacrated with argon or oxygen for $20 \mathrm{~min}$. The solution was irradiated with a monochromatic light (290 $\mathrm{nm} \pm \mathrm{J}(0)$ for $30 \mathrm{~min}$.

Acknowletgment. This rescarch was supporled by the Brain Korca 21 project in 2002 and Korca Basic Science Institute in 2001 .

\section{References}

1. Paramasivam. R.: Palaniappant. R.: Ramakrishnan. V. T. f. Chem. Soc (Them. Comm 1979. 260.

2. Jayanthi, $G$.: Muthusamy, S.: Paramesivam, R.: Ramakrishnen, V. T. J. Org ( $/ k^{\prime} n$. 1997.62.5766.

3. Bowman. W. S.: Heaney. H.: Smith. Г. H. G. Tetrohedron Lett. 1982. 23. 5093.

4. Couture. A.: Grandelaudon. P. Heterocycles 1984. 22. 1383.

5. Park, Y.T.: Jung C - -1 L: Kim. K.-W.: Kim. H. S. J. Org. Chem. 1999.64 .8546$.

6. Mayoul. A. M.: Park. Y.-1. J. Photoscience 2000, 7.5

7. Park. Y.-T.: Kim. M.-S.: Kwak. Y.-W.: Lo. J.-K:: Yoh. S.-D. J. Photoscience 2000. 7. 135.

8. Johnstone. R. A. W.: Payling. D. W. J. Chom Soc (C) 1969. 16. 2223.

9. Photo-lities type product was identified by $\mathrm{GCM}$ Malss. The regiochemistry of acetyl group on chloroamiline (between o- and $p$ - and position) is not determined. 